\title{
Polymorphisms in the 5' Flanking Region and First Exon of Insulin-Like Growth Factor 1 Gene in Southern Populations of Buffalo
}

\author{
${ }^{1}$ Saber Khederzadeh and ${ }^{2}$ Ahmad Yazdanpanah \\ ${ }^{1}$ Department of Genetic and Biotechnology, Faculty of Biological Sciences, \\ Varamin-Pishva Branch, Islamic Azad University, Varamin, P.O. Box 33817-74895, Iran \\ ${ }^{2}$ Department of Animal Sciences, Faculty of Animal Sciences and Food Industries, \\ Ramin Agricultural and Natural Resources University, Mollasani, P.O. Box 63417-73637, Iran
}

Received 2012-08-08, Revised 2012-07-02; Accepted 2013-07-24

\begin{abstract}
The Insulin-like Growth Factor 1 (IGF-1) system plays a critical endocrine role controlling nutrient metabolism in animals and it is a group of structurally-related polypeptides that regulate the growth of many types of mammalian cells. In liver, IGF-1 is dynamically regulated by lactation and energy balance. Less is known about the regulation of IGF-1 and IGF-binding protein mRNA in reproductive tissues and plays an important role in bovine follicular growth, acquisition of oocyte competence and embryo viability. The present study describes Polymorphisms in the IGF-1 Gene of Buffalo population in south of Iran. In order to characterization polymorphism, blood sample were collected from 95 buffalos from Ahvaz, Dezful, Shushtar, Shadegan and Susangerd cities. DNA extraction was based on Boom method and exon 1 of the IGF-1 gene was amplified to produce a $250 \mathrm{bp}$ fragment. The amplified fragment were digested with Eco105I (SnaBI) restriction endonuclease. Also, the $265 \mathrm{bp}$ of IGF-1 promoter in the 5' Flanking Region was amplified and subsequently subjected to Single Strand Conformation Polymorphism (SSCP). The results were revealed one pattern (B) in digestion and all the five populations were monomorph. But, the populations exhibited three different SSCP patterns. It is possible that this gene has not exposed to selection and inbreeding is estimated high.
\end{abstract}

Keywords: Buffalo, Polymorphism, IGF-1 Gene, Flanking Region, SSCP

\section{INTRODUCTION}

Genetic evaluation of animal performance has been accomplished by quantitative approaches which depend on molecular technology for identifying genes of economically interesting traits and analysis of the polymorphism of genes whose products are key enzymes in the metabolic pathways of important physiological processes and are related to phenotypes (Beuzen et al., 2000). Candidate genes have known biological functions related to the development or physiology of an important trait (Rothschild et al., 1997). Such genes can encode structural proteins or a member in a regulatory or biochemical pathway affecting the expression of the trait (Bryne and McMullen, 1996) and can be tested as putative QTLs (Yao et al., 1996). The Growth Hormone (GH) and Insulin-like Growth Factor 1 (IGF-1) genes are candidates for growth in bovine, since they play a key role in growth regulation and development (Breier, 1999). Genetic polymorphism in native breeds is a major concern considering the necessity of preserving genetic resources. It is very important to characterize genetically indigenous breeds (Bastos et al., 2001). Insulin-like growth factors 1 and 2 (somatomedins-IGF-1 and IGF-2) are structurally related proteins, playing a key role in cell differentiation, embryogenesis, growth and Corresponding Author: Saber Khederzadeh, Department of Genetic and Biotechnology, Faculty of Biological Sciences, Varamin-Pishva branch, Islamic Azad University, Varamin, P.O. Box 33817-74895, Iran 
regulation of metabolism. IGF1 and IGF2 were first identified by Salmon and Daughaday $(1956 ; 1957)$ and designated 'sulphationfactor' due to their ability to incorporate sulphate into ratcartilage in vitro. They were also known as Non-Suppressible Insulin-Like Activity (NSILA) I and II (Froesch et al., 1963). A decade later, the terms sulphation factor and NSILA were replaced by the term 'somatomedin'(Daughaday et al., 1972) and subsequently they were renamed 'IGFs 1 and 2' due to their structural similarity with insulin and their growthpromoting activities (Rinderknecht and Humbel, 1976a; 1976b). IGF1 is one of two ligands of the IGF family (Hwa et al., 1999; Spicer, 2004). The established components of the IGF system also include two receptors, six high-affinity IGF-Binding Proteins (IGFBPs) and IGFBP proteases (Giudice, 1995; Hwa et al., 1999; Spicer, 2004). Furthermore, another group of low-affinity binding proteins, known as IGFBP-related proteins (IGFBP-rPs), belongs to the IGF family. However, no final nomenclature has been agreed for these proteins, as several research groups have identified the same protein and each group has used a different nomenclature (Hwa et al., 1999; Rosenfeld et al., 2001). Potential receptors for IGFBP(s) and IGFBP-RP (s) have also been reported to be part of the IGF family (Hwa et al., 1999) (Table 1). Due to similarities in structure and sharing intracellular signalling cascades with other members of the IGF system, insulin, its receptor and a hybrid insulin/IGF receptor are also considered to be part of the IGF superfamily (Jones and Clemmons, 1995; Monget and Martin, 1997; McCusker, 1998; Poretsky et al., 1999; Butler and Roith, 2001; Juul, 2003). Insulin-like Growth Factor I (IGF1) is known to play an important role in various aspects of muscle growth and development (Davis and Simmen, 2006). Due to the effect of IGF1 on the hypertrophy of muscle cells, muscle fibre diameter can be affected by IGF1 (Musaro et al., 2001). Since increasing muscle fibre diameter may decrease tenderness, it can be postulated that IGF1 may also affect tenderness by increasing the size of the muscle fibres (Koohmaraie et al., 1995). The aim of this study was to investigate relationship between DNA polymorphisms in the IGF1 gene and tenderness and muscle development. IGF-1 is a polypeptide of the molecular weight $7.5 \mathrm{kDa}$ built of 70 amino acids (Daughaday and Rotwein, 1989). The amino acid sequence of IGF-1 is identical in humans, cattle, dogs and pigs (Nixon et al., 1999). In humans the IGF-1 gene contains 6 exons and is about $90 \mathrm{kbp}-$ long (Rotwein et al., 1986; Steenbergh et al., 1991). Due to an alternative splicing of exons 1 and 2, two different transcripts are formed: The one with exon 1 containing 1155 nucleotides (nt), while the other one, with exon 2, is shorter and contains $750 \mathrm{nt}$.
Table 1. The insulin-like growth factor superfamily (Velazquez et al., 2009)

\begin{tabular}{|c|c|c|}
\hline Ligands & & Receptors \\
\hline IGF1 & & Type 1 IGF receptor \\
\hline IGF2 & & $\begin{array}{l}\text { Type } 2 \text { IGF or IGF } 2 / \\
\text { mannose- } 6 \text {-phosphate }\end{array}$ \\
\hline $\begin{array}{l}\text { Binding } \\
\text { protein }\end{array}$ & $\begin{array}{l}\text { Binding } \\
\text { protein proteases }\end{array}$ & $\begin{array}{l}\text { (IGF2/M6P) receptor } \\
\text { Binding protein-related proteins } \\
\text { IGFBP-rP1 a }\end{array}$ \\
\hline IGFBP1 & IGFBP2 proteases & (IGFBP7/MAC25/TAF/PSF \\
\hline IGFBP2 & IGFBP3 proteases & IGFBP-rP2 a (CTGF \\
\hline IGFBP3 & IGFBP4 proteases & IGFBP-rP3 a (NovH) \\
\hline IGFBP4 & IGFBP5 proteases & IGFBP-rP4 a (CYR61) \\
\hline IGFBP5 & & IGFBP-rP5 a (L56/HTRA1) \\
\hline \multirow[t]{5}{*}{ IGFBP6 } & & IGFBP-rP6 a (ESM1 \\
\hline & Potential receptors & IGFBP-rP7 a \\
\hline & IGFBP(s) & (rCOP-1/WISP2/CTGF-L) \\
\hline & IGFBP-rP(s) & IGFBP-rP8 a (ELM1/WISP1) \\
\hline & & IGFBP-rP9 a (WISP3 \\
\hline
\end{tabular}

Production of these transcripts is controlled by two different promoters both containing canonical regulatory sequences-TATA-box and CCAAT-box (Jansen et al., 1991). It was shown that transcripts of both classes are differentially expressed in various tissues, being, however, most abundant in liver (Wang et al., 2006). In vertebrates, the Insulin-Like Growth Factor 1 (IGF1) or somatomedin gene plays a key role in various physiological and metabolic processes, where IGF1 and growth hormone or somatotrophin is involved in the somatotropic axis. IGF1 is a mediator of many biological effects; for example, it increases the absorption of glucose, stimulates my genesis, inhibits apoptosis, participates in the activation of cell cycle genes, increases the synthesis of lipids, stimulates the production of progesterone in granular cells and intervenes in the synthesis of DNA, protein, RNA and in cell proliferation (Etherton, 2004). The bovine IGF1 gene was mapped on chromosome 5 , in the centimorgan 73.5 (Grosse et al., 1999). The provisional nucleotide sequence is approximately $72 \mathrm{~kb}$ (ID number 281239). In humans, pigs, goats, rats and chickens, the IGF1 nucleotide sequence is about 70-90 kb (Rose, 2002). Exon number is different between species; for example, goats, pigs and sheep have 1-6 exons (Mikawa et al., 1995) and humans and rats 1-5 (Rotwein et al., 1986). The IGF-1 gene is extremely conserved among species and few polymorphisms are described. The presence of a microsatellite at the promoter region of this gene in bovine, human and horse allows to analyze genetic variations related to this locus (Kirkpatrick, 1992). Evidence of selection effects on allele frequencies at these two loci was found in the traditional lineage of Canchim (Regitano et al., 1999). Nucleotide sequence 
polymorphisms were identified in the bovine IGF-1 gene and their correlations with animals' growth rate and meat performance traits were found. The Short Tandem Repeat (STR) polymorphism in the 5'-flanking region and the Single Strand Conformation Polymorphism (SSCP) in intron 3 of the IGF-1 were reported by Kirkpatrick (1992). In Hereford cattle the STR polymorphism was shown to be associated with body weight at birth and at weaning and with the growth rate (Moody et al., 1996). Such associations were not found in other beef breeds (Curi et al., 2005). The SSCP in the 5'-flanking region of IGF-1 was found by Ge et al. (1997) in Angus cattle. This polymorphism was then identified as T/C transition, also recognizable as RFLPSnaBI (Ge et al., 2001). Two alleles and three genotypes were found. Allele A (with nt T at position472) appeared significantly more frequent than allele B (with nt $\mathrm{C}$ ) in a group of animals selected for the high IGF-1 content of blood. However, the BB genotype (with nucleotides $\mathrm{CC}$ ) was found to be associated with higher body weight at weaning (Li et al., 2004). No association was found between IGF-1 RFLP-SnaBI and dairy production traits in Holstein cattle (Hines et al., 1998). Two polymorphisms in the IGF-1 were reported by Lien et al. (2000) in Norwegian cattle: The TTTG insertion/deletion (InDel) in intron 4 and the RFLP-DpnI in intron 5. However, the effects of these polymorphisms on beef or milk production traits were not investigated. The objective of the present study was to investigate in the 5' Flanking Region and exon 1 of IGF-1 Gene in southern populations of Iranian Buffalo in Khuzestan province of IRAN using PBR (PCR Based RFLP) and SSCP technique.

\section{MATERIALS AND METHODS}

\subsection{Animals and Sampling}

In current study, Random blood samples were collected from 95 Buffalos from five populations involve: Ahvaz, Shadegan, Susangerd, Dezful and Shushtar cities in Khuzestan province of Iran (Fig. 1). Approximately, 3 $\mathrm{ml}$ blood sample was gathered from venom in EDTA tube and was transferred to $-20^{\circ} \mathrm{C}$ freezer.

\subsection{DNA Extraction and PCR Amplification}

Genomic DNA was isolated by using DNA Extraction Kit (Diatom) and was based on Boom et al. (1989) method. Quantity was determined by measuring the absorbance at $260 \mathrm{~nm}$ and the concentration, purity and quality were determined by measuring the absorbance at 260/280 $\mathrm{nm}$ and 230/260 ratios using a
NanoDropTM 1000 spectrophotometer (Thermo Scientific). DNA extractions were appropriately labeled and stored at $-20^{\circ} \mathrm{C}$ for analysis. The study was concentrated on a $250 \mathrm{bp}$ fragment of IGF-1 gene spanning over exon 1. Primer sequences for PCR were established by Ge et al. (1997; 2001) (Table 2). The PCR reaction volume of $25 \mu \mathrm{L}$ contained approximately $100 \mathrm{ng}$ of genomic DNA, 1unit Taq DNA Polymerase, $1 \times$ PCR Buffer, $1.5 \mathrm{mM} \mathrm{MgCl} 2,200 \mu \mathrm{M}$ dNTPs and 0.3 pMol of each primer. Amplification conditions included an initial denaturation at $95^{\circ} \mathrm{C}$ for $5 \mathrm{~min}$, followed by 35 cycles at $94^{\circ} \mathrm{C}$ for $30 \mathrm{~s}, 63^{\circ} \mathrm{C}$ for $30 \mathrm{~s}$ and $72^{\circ} \mathrm{C}$ for $40 \mathrm{~s}$, followed by a final extension at $72^{\circ} \mathrm{C}$ for $5 \mathrm{~min}$.

\subsection{Enzyme Digestion}

The amplified fragment was digested with Eco105I (SnaB I). The digestion reaction contained by $5 \mu \mathrm{L}$ of PCR product, $2 \mu \mathrm{L}$ Buffer $10 \times, 5 \mathrm{U}$ of Eco105I (SnaB I) and $\mathrm{H}_{2} \mathrm{O}$ up to a total volume of $20 \mu \mathrm{L}$ then were incubated at $37^{\circ} \mathrm{C}$ for $12-16 \mathrm{~h}$. The digestion products were electrophoresed on $2 \%$ agarose gel in $0.5 \times \mathrm{TBE}$ and visualized by ethidium bromide staining for $40 \mathrm{~min}$ at 100 V. The Statistical analysis was calculated using Popgene32 software (version 1.31).

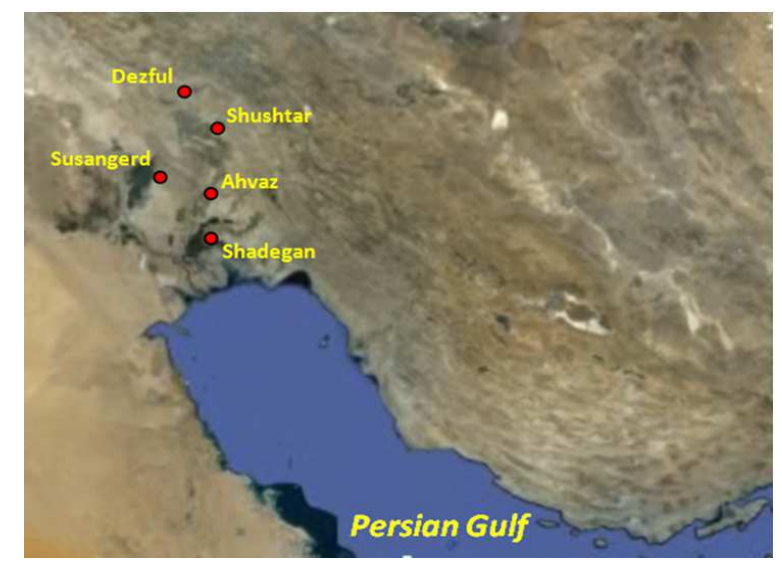

Fig. 1. Geographical location of the populations studied

Table 2. Primer used in the amplification in the bovine IGF1 gene

\begin{tabular}{llll}
\hline Primer & $\begin{array}{l}\text { Primer } \\
\text { sequence }\end{array}$ & $\begin{array}{l}\text { PCR product } \\
\text { size (bp) }\end{array}$ & Reference \\
\hline IGF677 & ATTACAAAG & & \\
& CTGCCTGCCCC & & \\
IGF897 & ACCTTACCC GTATG 250 & Ge et. (2001) \\
& AAAGGAATATACGT & \\
IGF677 & GGGGCAGGC & & \\
& AGCTTTGTAAT & & Ge et al. (1997) \\
\hline
\end{tabular}




\subsection{Single-strand Polymorphism Analysis (SSCP)}

For SSCP analysis, $5 \mathrm{ml}$ of PCR product and $10 \mathrm{~mL}$ of diluting dye were denatured at $95^{\circ} \mathrm{C}$ for $10 \mathrm{~min}$ and immediately plunged into ice for $5 \mathrm{~min}$. The dilution was loaded on to a $12 \%$ polyacrylamide gel with $10 \%$ glycerol. The gel was run at a constant voltage of $250 \mathrm{~V}$ at $20^{\circ} \mathrm{C}$ for $24 \mathrm{~h}$ and gels were silver stained.

\section{RESULTS}

The amplified of promoter in the 5' Flanking Region and exon 1 of IGF-1 Gene resulted in a DNA fragment with $250 \mathrm{bp}$ and $265 \mathrm{bp}$ with PCR technique (Fig. 2). Analysis of exon 1: The results were revealed one pattern (B) in digestion, resulting in one genotype and all the five populations were monomorph. one allele (B) was observed, The Eco105I (SnaB I) indicated single restriction pattern in all the populations of buffalo and it didn't produce digestion fragments pattern (bands of approximately 226 and $23 \mathrm{bp}$ ) in southern populations of Iranian buffalo. This study had no impact which agrees with the results obtained in cattle with similar gene locus of IFG-1 (Laureano et al., 2006). The animals with one allele were assigned with BB genotype (Fig. 3). A and B allele frequencies were 0.0000 and 1.0000 , respectively. The high frequency of the B allele suggests that this allele Variant might have been favored by selection for production traits. The observed Homozygosity and heterozygosity were 1.000 and 0.000 , respectively (Table 3). Analysis of promoter in the 5' Flanking Region: The PCR-SSCP analysis revealed three distinct patterns (Fig. 4).

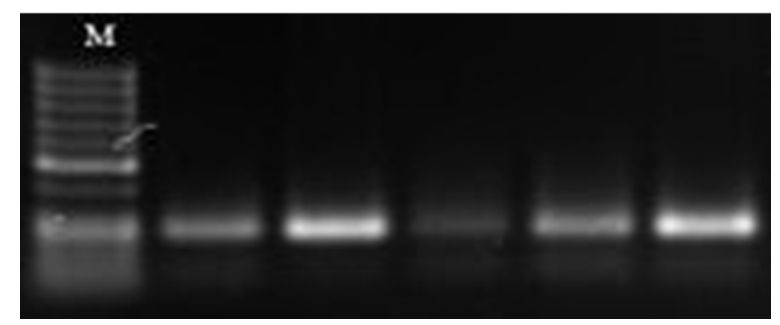

Fig. 2. PCR products of IGF-1 (Size obtained: $250 \mathrm{bp}$ )

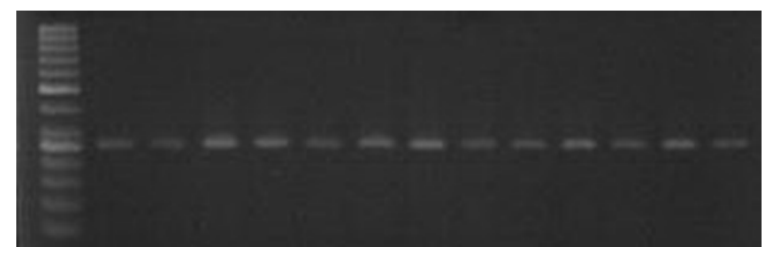

Fig. 3. IGF-1 genotyping by PBR method (2\% agaros gel)
All the five populations, the means of frequencies were $47.5 \%$ for pattern $1,41 \%$ for pattern $2,11.5 \%$ for pattern 3 . We observed most frequency in pattern of 1 and low frequency in pattern 3. This study had impact which agrees with the results obtained in bufallo with similar locus of IFG-1 (Fatima et al., 2009).

\section{DISCUSSION}

Candidate genes have known biological functions related to the development or physiology of an important trait. Such genes can encode structural proteins or a member in a regulatory or biochemical pathway affecting the expression of the trait (Bryne and McMullen, 1996) and can be tested as putative QTLs (Yao et al., 1996). The study by Ge et al. (2001) characterizes a $\mathrm{G} \rightarrow \mathrm{A}$ transition polymorphism within an Eco130I site of intron 3 of the IGF1 gene in swamp buffaloes (Bubalus b. bubalis kerebau). Polymorphisms in the bovine IGF-I gene are associated with circulating IGF-I concentrations and growth traits. Growth in animals is controlled by a complex system, in which the somatotropic axis plays a key role. Genes that operate in the somatotropic axis are responsible for the postnatal growth, mainly GH that acts on the growth of bones and muscles mediated by IGF-1 (Sellier, 2000).

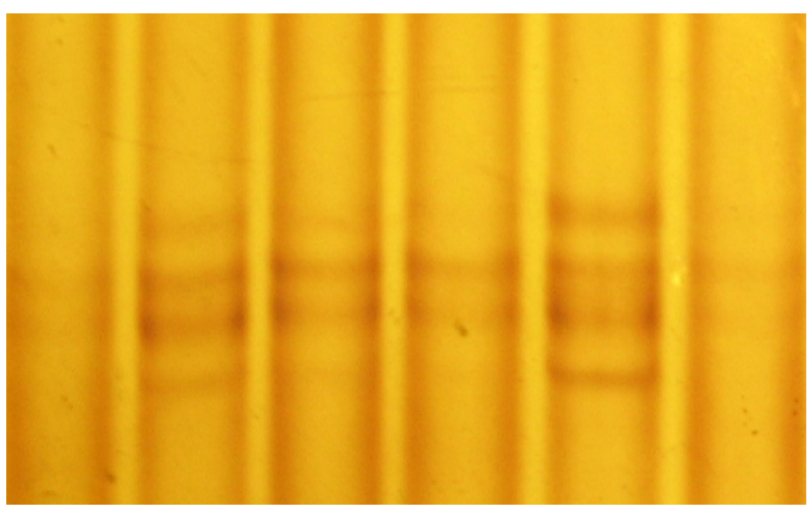

Fig. 4. The distinct patterns of SSCP analysis

Table 3. The Homozygosity and heterozygosity in different

\begin{tabular}{lcc}
\multicolumn{2}{c}{ regions } & \\
\hline Regions & Homozygosity & Heterozygosity \\
\hline Ahvaz & 1.000 & 0.000 \\
Dezfol & 1.000 & 0.000 \\
Shushtar & 1.000 & 0.000 \\
Shadegan & 1.000 & 0.000 \\
Susangerd & 1.000 & 0.000 \\
\hline
\end{tabular}




\section{CONCLUSION}

The southern populations of Iranian Buffalo showed a low degree of genetic diversity for the IGF1 locus. Also, random genetic drift can be one of the causes of the homozygosity. Although we observed the low variability for exon 1 but there was high degree of genetic diversity for the 5' Flanking Region of IGF-1 gene. In the other hand, this data provide evidence that buffalo populations have a good polymorphism for some gene, which opens interesting prospects for future selection programs, especially marker assistant selection between different genotypes of different locus and milk, gain and meat traits. The genetic variation of 265 bp fragment used in Present Results showed that PCR-RFLP (PBR) is appropriate tools for evaluating genetic variability.

\section{ACKNOWLEDGMENT}

The current study was supported by Faculty of Animal Sciences and Food Industries, Ramin Agricultural and Natural Resources universities.

\section{REFERENCES}

Bastos, E., A. Cravador, J. Azevedo and H. Guedes, 2001. Single strand conformation polymorphism (SSCP) detection in six genes in Portuguese sheep breeds Churra da terra Quente. Biochtechnol. Agron. Soc. Environ., 5: 7-15.

Beuzen, N.D., M.J. Stear and K.C. Chang, 2000. Molecular markers and their use in animal breeding. Vet. J., 160: 42-52. PMID: 10950134

Boom, R., Sol C.J.A., Salimans M.M.M., Jansen C L., 1989. Rapid and simple method for purification of nucleic acids. J. Clin. Microbiol., 28: 495-503. PMID: 1691208

Breier, B.H., 1999. Regulation of protein and energy metabolism by the somatotropic axis. Domest, Anim. Endocrinol., 17: 209-218. PMID: 10527124

Bryne, P.F. and M.D. McMullen, 1996. Defining genes for agricultural traits: QTL analyses and the candidate gene approach. Probe, 7: 24-27.

Butler, A.A. and D.L. Roith, 2001. Control of growth by the somatropic axis: Growth hormone and the insulin-like growth factors have related and independent roles. Annu. Rev. Physiol., 63: 141164. PMID: 11181952
Curi, R.A., H.N.D. Oliveira, A.C. Silveira, C.R. Lopes, 2005 . Effects of polymorphic microsatellites in the regulatory region of IGF1 and GHR on growth and carcass traits in beef cattle. Anim. Genet., 36: 58-62. PMID: 15670132

Daughaday, W.H. and P. Rotwein, 1989. Insulin-like growth factors I and II. Peptide messenger ribonucleic acid and gene structures, serum and tissue concentrations. Endocr. Rev., 10: 68-91. PMID: 2666112

Daughaday, W.H., K. Hall, M.S. Raben, W.D.J. Salmon and J.L.V.D. Brande et al., 1972. Somatomedin: Proposed designation for sulphation factor. Nature, 235: 107-107. PMID: 4550398

Davis, M.E. and R.C.M. Simmen, 2006. Genetic parameter estimates for serum insulin-like growth factor I concentrations and body weight and weight gains in Angus beef cattle divergently selected for serum insulin-like growth factor I concentration. J. Anim. Sci., 84: 2299-2308. DOI: 10.2527/jas.2005-567

Etherton, T.D., 2004. Somatotropic function: The somatomedin hypothesis revisited. J. Anim. Sci., 82: E239-E244. PMID: 15471803

Fatima, S., S.M. Bhatt, C.D. Bhong, D.N. Rank and C.G. Joshi, 2009. Genetic polymorphism study of igf-i gene in buffaloes of gujarat. Buffalo Bull., 28: 159-164.

Froesch, E.R., H. Buorgi, E.B. Ramseier, P. Bally and A. Labhart, 1963. Antibody-suppressible and nonsuppressible insulin-like activities in human serum and their physiologic significance. An insulin assay with adipose tissue of increased precision and specificity. J. Clin. Invest., 42: 1816-1834. DOI: 10.1172/JCI104866

Ge, W., M.E. Davis and H.C. Hines, 1997. Two SSCP alleles detected in the 5'-flanking region of the bovine IGF-1 gene. Anim. Genet., 28: 155-156. PMID: 9172322

Ge, W., M.E. Davis, H.C. Hines, K.M. Irvin and R.C.M. Simmen 2001. Associations of a genetic marker with blood serum insulin-like growth factor-1 concentration and growth traits in Angus cattle. J. Anim. Sci., 79: 1757-1762. PMID: 11465363

Giudice, L.C., 1995. The insulin-like growth factor system in normal and abnormal human ovarian follicle development. Am. J. Med., 98: 48S-54S. PMID: 7825641

Grosse, W.M., S.M. Kappes, W.W. Laegreid and J.W. Keele, 1999. Single Nucleotide Polymorphism (SNP) discovery and linkage mapping of bovine cytokine genes. Mamm. Genome., 10: 1062-1069. PMID: 10556424 
Hines, H.C., W. Ge, Q. Zhao and M.E. Davis, 1998. Association of genetic markers in growth hormone and insulin-like growth factor I loci with lactation traits in Holsteins. Anim. Genet., 29: 69-69.

Hwa, V., Y. Oh and R.G. Rosenfeld, 1999. The insulinlike growth factor-binding protein (IGFBP) superfamily. Endocrine Rev., 20: 761-787. PMID: 10605625

Jansen, E., P.H. Steenbergh, D. Leroith, J.C.T. Roberts and J.S. Sussenbach, 1991. Identication of multiple transcription start sites in the human insulin-like growth factor I gene. Mol. Cellular Endocrinol., 78: 115-125. PMID: 1936520

Jones, J.I. and D.R. Clemmons, 1995. Insulin-like growth factors and their binding proteins: Biological actions. Endocr. Rev., 16: 3-34. PMID: 7758431

Juul, A., 2003. Serum levels of insulin-like growth factor $\mathrm{I}$ and its binding proteins in health and disease. Growth Horm. IGF Res., 13: 113-170. PMID: 12914749

Kirkpatrick, B.W., 1992. Identification of a conserved microsatellite site in the porcine and bovine insulinlike growth factor-I gene 5' flank. Anim. Genet., 23: 543-548. PMID: 1492707

Koohmaraie, M., S.D. Shackelford, T.L. Wheeler, S.M. Lonergan and M.E. Doumit, 1995. A muscle hypertrophy condition in lamb (callipyge): Characterization of effects on muscle growth and meat quality traits. J. Anim. Sci., 73: 3596-3607.

Laureano, M.M., A.R. Otaviano, R.B, Costa, A.L. Lima, A.K. Salman and H. Tonhati et al., 2006. Characterization of polymorphisms within insulinlike growth factor-I and prolactin genes of three groups of Nellore heifers. Proceedings of the 8th World Congress on Genetics Applied to Livestock Production. 13-18-2006, Belo Horizonte, Minas Gerais, Brazil, pp: 10-10.

Li, C., J. Basarab, W.M. Snelling, B. Benkel, B. Murdoch and C. Hansen et al., 2004. Assessment of positional candidate genes myf5 and IGF1 for growth on bovine chromosome 5 in commercial lines of Bos taurus. J. Anim. Sci., 82: 1-7. PMID: 14753343

Lien, S., A. Karlsen, G. Klemetsdal, D.I. Vage, I. Olsaker and H. Klungland et al., 2000. A primary screen of the bovine genome for quantitative trait loci affecting twinning rate. Mammalian, Genome, 11: 877-882. DOI: $10.1007 / \mathrm{s} 003350010180$

McCusker, R.H., 1998. Controlling insulin-like growth factor activity and the modulation of insulin-like growth factor binding protein and receptor binding. J. Dairy Sci., 81: 1790-1800. PMID: 9684185
Mikawa, S., G. Yoshikawa, H. Aoki, Y. Yamano, et al. 1995. Dynamic aspects in the expression of the goat Insulin-like Growth Factor-I (IGF-I) gene: Diversity in transcription and post-transcription. Biosci. Biotechnol. Biochem., 59: 87-92. PMID: 7765981

Monget, P. and G.B. Martin, 1997. Involvement of insulin-like growth factors in the interactions between nutrition and reproduction in female mammals. Hum. Reprod., 12: 33-52. PMID: 9403320

Moody, D.E., D. Pomp, S. Newman and M.D. Macneil, 1996. Characterization of DNA polymorphisms in three populations of Hereford cattle and their associations with growth and maternal EPD in line 1 Herefords. J. Anim. Sci., 74: 1784-1793. PMID: 8856432

Musaro, A., K. McCullagh, A. Paul, L. Houghton and G. Dobrowolny, 2001. Localized Igf-1 transgene expression sustains hypertrophy and regeneration in senescent skeletal muscle. Natu. Genet., 27: 195-200. DOI: $10.1038 / 84839$

Nixon, A.J., B.D.B. Toland and L.J. Sandell, 1999. Primary nucleotide structure of predominant and alternate splice forms of equine insulin-like growth factor I and their gene expression patterns in tissues. Am. J. Vet. Res., 60: 1234-1241. PMID: 10791936

Poretsky, L., N.A. Cataldo, Z. Rosenwaks and L.C. Giudice, 1999. The insulin-related ovarian regulatory system in health and disease. Endocrine Rev., 20: 535-582. DOI: 10.1210/er.20.4.535

Regitano, L.C.A., J.L. Azevedo, R. Vencovsky, I.U. Packer and P.F. Barbosa et al., 1999. Selection for breed-specific growth hormone and IGF-1 alleles in a synthetic beef cattle cross, Canchim. Genet. Mol. Biol., 22: 531-537. DOI: 10.1590/S141547571999000400011

Rinderknecht, E. and R.E. Humbel, 1976a. Polypeptides with nonsuppressible insulin-like and cell-growthpromoting activities in human serum: Isolation, chemical characterization and some biological properties of forms I and II. Proc. Natl. Acad. Sci. USA., 73: 2365-2369. PMID: 1065887

Rinderknecht, E. and R.E. Humbel, 1976b. Aminoterminal sequences of two polypeptides from human serum with nonsuppressible insulin-like and cellgrowth-promoting activities: Evidence for structural homology with insulin B chain. Proc. Natl. Acad. Sci. USA., 73: 4379-4381. PMID: 1069990 
Rose, M.T., 2002. The somatotropic axis of the dairy cow revisited. Anim. Sci. J., 73: 13-19. DOI: 10.1046/j.1344-3941.2002.t01-1-00002.x

Rosenfeld, R.G., V. Hwa and O. Youngman, 2001. Nomenclature of the insulin-like growth factorbinding protein superfamily. J. Clin. Endocrinol. Metab., 86: 946-946. DOI: 10.1210/jc.86.2.946

Rothschild, M.F., L.A. Messer and A. Vincent, 1997. Molecular approaches to improved pig fertility. J. Reprod Fertil. Suppl., 52: 227-236. PMID: 9602731

Rotwein, P., K.M. Pollock, D.K. Didier and G.G. Krivi, 1986. Organization and sequence of the human insulin-like growth factor I gene. Alternative RNA processing produces two insulin-like growth factor I precursor peptides. J. Biol. Chem., 261: 4828-4832. PMID: 2937782

Salmon, W.D.J. and W.H. Daughaday, 1956. Sulfation factor, a serum component mediating the action of growth hormone in stimulating incorporation of sulfate into cartilage. J. Clin. Investigation, 35: 733733.

Salmon, W.D.J. and W.H. Daughaday, 1957. A hormonally controlled serum factor which stimulates sulfate incorporation by cartilage in vitro. J. Lab. Clin. Med., 149: 825-836. PMID: 13429201

Sellier, P., 2000. Genetically caused retarded growth in animals. Domest. Anim. Endocrinol., 19: 105-119. PMID: 11025190
Spicer, L.J., 2004. Proteolytic degradation of insulin-like growth factor bindingproteins by ovarian follicles: A control mechanism for selection of dominant follicles. Biol. Reprod., 70: 1223-1230. PMID: 14668213

Steenbergh, P.H., A.M.C.B. Koonen-Reemst, C.B.J.M. Cleutjens and J.S. Sussenbach, 1991. Complete nucleotide sequence of the high molecular weight human IGF-1 mRNA. Biochem. Biophy. Res. Commun., 175: 507-514. PMI D: 2018498

Velazquez, M.A., J. Zaraza, A. Oropeza, R. Webb and H. Niemann, 2009. The role of IGF1 in the in vivo production of bovine embryos from superovulated donors. Reproduction, 137: 161-180. PMID: 19029343

Wang, T.H., C.L. Chang, H.M. Wu, Y.M. Chiu, C.K. Chen and H.S. Wang, 2006. Insulin-like Growth Factor-II (IGF-II), IGF-Binding Proteins-3 (IGFBP3) and IGFBP-4 in follicular fluid are associated with oocyte maturation and embryo development. Fertil. Steril., 86: 1392-1401. PMID: 17070193

Yao, J., S.E. Aggrey, D. Zadworny, J.F. Hayes and U. Kvhnlein, 1996. Sequence variations in the bovine growth hormone gene characterized by single-Strand Conformation Polymorphism (SSCP) analyses and their association with milk production traits in Holstein. Genetics, 144: 1809-1816. PMID: 8978066 